\title{
CHROMATOGRAPHIC DETERMINATION OF TOLUENE AND ITS METABOLITES IN URINE FOR TOLUENE EXPOSURE - A REVIEW
}

\author{
(Penentuan Kromatografi Toluena dan Metaboliknya di dalam Urin bagi Pendedahan \\ Toluena - Satu Ulasan) \\ Mohamad Raizul Zinalibdin ${ }^{1,2}$, Abdul Rahim Yacob ${ }^{1}$, Mohd Marsin Sanagi ${ }^{1,3 *}$ \\ ${ }^{1}$ Department of Chemistry, Faculty of Science, \\ Universiti Teknologi Malaysia, 81310 UTM Johor Bahru, Johor, Malaysia \\ ${ }^{2}$ Department of Chemistry, \\ Johor Branch, Jalan Abdul Samad, 80100 Johor Bahru, Johor, Malaysia \\ ${ }^{3}$ Centre for Sustainable Nanomaterials, \\ Ibnu Sina Institute for Scientific and Industrial Research, \\ Universiti Teknologi Malaysia, 81310 UTM Johor Bahru, Johor, Malaysia \\ *Corresponding author: marsin@kimia.fs.utm.my
}

Received: 1 November 2015; Accepted: 10 March 2016

\begin{abstract}
The determinations of toluene and their metabolites in biological samples such as urine and blood allow the estimation of the degree of exposure to this chemical. Chromatographic methods and preliminary methods are now universally employed for this purpose. Preliminary color test methods are well established for qualitative determination of toluene and its metabolites. Mobile test kits using color test methods are a vast tool for screening urine samples but chromatographic methods are still needed for confirmation and quantitative analysis. Gas chromatography (GC) methods are well-adapted for the determination of toluene metabolite in urine, but these methods often require several pretreatment steps. Meanwhile, high performance liquid chromatography (HPLC) is becoming a powerful tool for the accurate and easy determination of toluene metabolites considering its decisive advantages for routine monitoring. Furthermore, recent development in HPLC could widen the usefulness of this method to solve the most complex analytical problems that could be encountered during the measurement.
\end{abstract}

Keywords: toluene, toluene metabolites, preliminary test, gas chromatography, high performance liquid chromatography

\begin{abstract}
Abstrak
Penentuan toluena dan metabolitnya dalam sampel biologi seperti urin dan darah membolehkan anggaran tahap pendedahan terhadap bahan kimia ini. Kaedah kromatografi dan kaedah awalan merupakan kaedah yang sering digunakan untuk tujuan ini pada masa kini. Kaedah awalan menggunakan ujian warna telah dibangunkan untuk penentuan kualitatif toluena dan metabolit. Kit ujian mudah alih menggunakan ujian warna meluas digunakan bagi pemeriksaan sampel urin tetapi kaedah kromatografi masih diperlukan untuk pengesahan analisis kuantitatif. Kaedah kromatografi gas adalah kaedah yang kerap digunakan bagi menentukan metabolit toluena dalam urin namun kaedah ini sering memerlukan beberapa langkah rawatan awal. Sementara itu, kromatografi cecair berprestasi tinggi (HPLC) menjadi alat yang berkuasa untuk penentuan tepat dan mudah metabolit toluena memandangkan kelebihannya yang jelas untuk pemantauan rutin. Tambahan pula, perkembangan terkini dalam HPLC boleh memperluaskan kegunaan kaedah ini bagi menyelesaikan masalah analisis rumit yang boleh dihadapi semasa pengukuran.
\end{abstract}

Kata kunci: toluena, metabolit toluena, ujian awalan, kromatografi gas, kromatografi cecair berprestasi tinggi 


\section{Introduction}

Volatile organic compounds (VOCs) are used as a component in a variety of domestic or industrial consumer products. This statement illustrates that humans always use and are frequently in contact with VOCs. Consumer products such as cleaning products, paints or thinner, glues, lighter, aerosols, cosmetics, fuels and others contain VOCs. Despite these, prolonged exposure to VOCs may lead to poisoning and sudden death $[1,2]$.

One of the major current issues among adolescents is misuse of the consumer products. In most of the cases, organic compounds contained in the consumer products are inhaled by them using different methods such as huffing, bagging and sniffing. Such conducts will deliver the desired effect such as feeling of pleasure, disinhibition, euphoria and hallucination [3, 4]. Unfortunately, the most difficult facet of the inhalant problem to confront is the fact that inhalants are everywhere.

Even though, there are many VOCs in consumer products, the concern is largely on toluene. This is because toluene has been the most widely used organic solvent in the industries since the second half of the last century [5-7].Such exposure to high concentrations of toluene has been reported by Watson [8]. Toluene biotransformation consists of several steps [9] involving side-chain oxidation where toluene is metabolized into benzoic acid and further conjugated with glycine to form hippuric acid [10]. Meanwhile, small amounts of absorbed toluene are oxidized at the aromatic ring and excreted in urine as $o$ - and $p$-cresol.

This review aims to present a summary of the toluene exposure pertaining to toluene metabolites and its potential biomarker, preliminary tests for toluene metabolites, sample pretreatment and determination of toluene metabolites using various instrumentations. From this review, researchers in this area are expected to gain a good idea of analytical procedures, analytical techniques and analytical instrumentations involved. It is our hope that this review will facilitate researchers to plan their own research on toluene exposure and to develop fast method and new separation technique using green technology, electrochemical sensors with mobile instrumentation and other related techniques. The discussion begins with a general topic about toluene exposure and its effects on humans. The metabolism of toluene in human body from its inhalation until excretion in urine is then described. The selection of potential biomarkers and indicators of exposure to toluene are also described in a considerable detail.

\section{Toluene exposure effects and analysis}

The preliminary test has become a vast tool for on-site screening of urine sample as many drugs and other poisons give characteristic colors with appropriate reagents if present in sufficient amounts and in the absence of interfering compounds. A few of these tests are only for practical purposes but usually compounds containing similar functional groups will also react and thus interferences from other poisons, metabolites or contaminants are to be expected. Color tests for toluene metabolites have been described including for hippuric acid [11] and $o$-cresol [12].

Methods for toluene analysis and the identification of a reliable indicator in toluene exposure have been described by many researchers. High Performance Liquid Chromatography (HPLC) represents a valuable tool for the routine monitoring of workers exposed to toluene. The determination of urinary metabolites of toluene using HPLC has been extensively studied including those focusing on hippuric acid [13-17], cresol [18] and S-benzyl mercapturic acid [19-20]. For the urinary determination of solvent metabolites, especially for monitoring purposes, HPLC is becoming a method of choice. This method offers decisive advantages in this area as it permits the simultaneous determination of several metabolites whether it is run in isocratic mode or by gradient analysis. This method provides a complete metabolic profile, detection of isomer compound, it is easily automated, and does not require extraction, derivatization steps or pre-treatment of samples.

Determination of toluene metabolites in complex mixtures such as biological fluids is well-known and established. The separation of toluene metabolites from biological fluid can easily be achieved by gas chromatography (GC) with headspace method [21, 22]. However, gas chromatography-mass spectrometry (GC-MS) appears very suitable for the identification of toluene and their metabolites [23-27]. Unfortunately, not all target compounds are amenable to GC due to their poor thermal stability or volatility. Polar compounds are an example of analytes that need the pretreatment of sample using derivatization processes and these together rendered GC less widely-employed compared to HPLC in the analysis of toluene and its metabolites. 


\section{Metabolism and potential biomarker of toluene: Historical background}

Hippuric acid has been a historical biomarker for toluene exposure but the validity of hippuric acid as an exposure marker is questionable as non-exposed subjects (background levels) were found to contain higher levels of hippuric acid compared to exposed subjects [28-31]. The value of the hippuric acid as a biomarker of occupational toluene exposure was further challenged by the presence of benzoate in some preservatives $[32,33]$ as benzoate is metabolized and excreted as a hippuric acid in urine [32, 34, 35].

Several researchers have considered a few other possible biomarkers for toluene exposure namely $o$-cresol [27, 36, 37], benzylmercapturic acid [19, 20,38] and toluylmercapturic acid [39]. Although hippuric acid has attracted considerable attention as an indicator of exposure to toluene, the fact that it can deliver false results of toluene exposure has prompted a number of researchers to suggest $o$-cresol be used as a biomarker, especially for the determination of low-level exposures to toluene. However, it was found that urinary $o$-cresol demonstrated false results too when it involved smoking and drinking counterpart [40] where it can reduce the amount of this chemical particularly at low levels of toluene exposure.

More recently, researchers found a new specific biological marker for toluene metabolites namely Sbenzylmercapturic acid (SBMA) [19, 20, 41]. SBMA was found to be a more specific biomarker compared to hippuric acid and $o$-cresol. It was found that SBMA was dependent only on airborne toluene and not effected by food preservative, smoking and drinking habit even at low level of exposure to toluene [42].

\section{Toluene metabolism}

According to Park et al. [43], toluene is the major solvent with the most documentation of abuse, possibly because of its relative low risk of sudden death and the ease of detection in blood. When many aromatic compounds such as toluene and benzoic acid are taken internally, they are converted to hippuric acid by reaction with the amino acid glycine [43]. In another paper, Anderson et al. [44] explained in detail that the principal metabolite of toluene is benzoic acid (approximately $80 \%$ of dose) which is conjugated with the glycine to form hippuric acid and directly excreted in urine (half-life of 2-3 hours).

Toluene can be absorbed into the blood stream from the lung and the gastrointestinal tract and through the skin and mucosa. In late 1980s, Ameno et al. described that the brain and liver serve as reservoir for toluene [45]. A few years later, Yamazaki et al., in their work explained that more than $80 \%$ of absorbed toluene is metabolized by mixoxidase enzyme system to benzoic acid and hippuric acid in the liver and kidney before excretion into the urine. Meanwhile, some absorbed toluene $(0.4-1.1 \%)$ is hydroxylated and excreted as a mixture of ortho-, para-, and meta-cresol. A schematic diagram for toluene metabolism in humans is shown in Scheme 1 [46].

Later on, Zuppi et al. [47] stated that the hippuric acid is biosynthesized from glycine, benzoic acid and CoA by enzymes located in the mitochondrial matrix of liver and kidney cells. This metabolic pathway provides an alternative flux of nitrogen from the usual urea precursors (ammonia, alanine and glutamate) to glycine and it is utilized for the detoxification of aromatic compounds such as toluene. Toluene is very hazardous to our health, with the potential of inflicting considerable pain and suffering until death to the sniffer.

Following inhalation or oral exposure to toluene, approximately $60-75 \%$ of absorbed toluene is metabolized to benzoic acid. The initial step involves side chain oxidation to benzyl alcohol by cytochrome P450 enzymes (Scheme 2). Benzyl alcohol is further oxidized to benzoic acid by alcohol dehydrogenase and aldehyde dehydrogenase. Benzoic acid is subsequently conjugated with glycine to form hippuric acid. Benzoic acid may also be conjugated with glucuronic acid to form benzoyl glucuronide in the urine. Less than $1 \%$ of absorbed toluene undergoes ring hydroxylation to form $o^{-}$, and $p$-cresol, which are excreted in the urine as glucuronide or sulphate conjugates as reported by Amorim et al. [48]. 


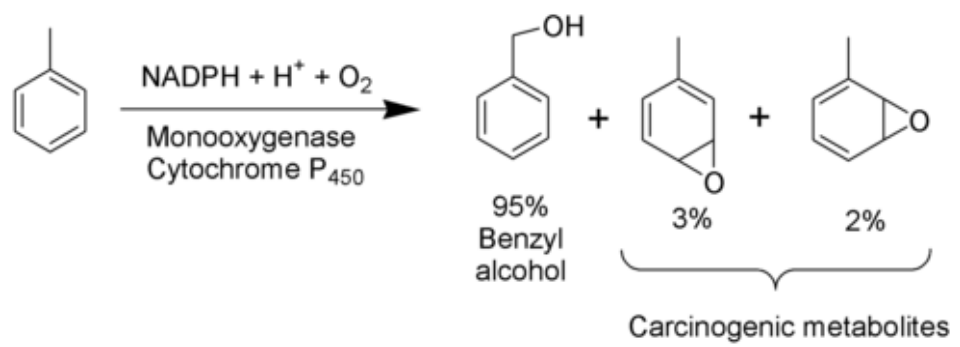

Scheme 1. First step of toluene metabolism [46]

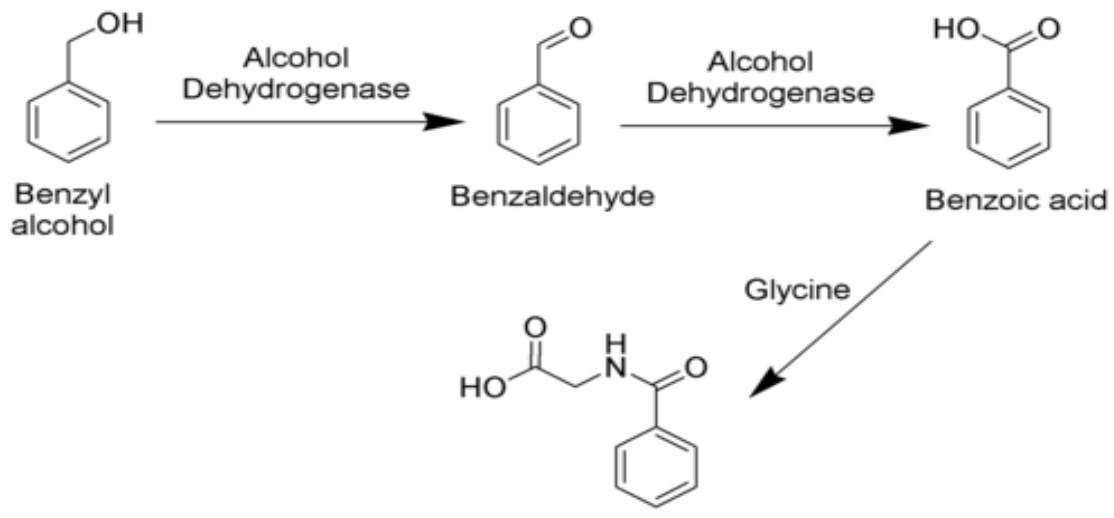

Hippuric acid

Scheme 2. Second step of toluene metabolism [46]

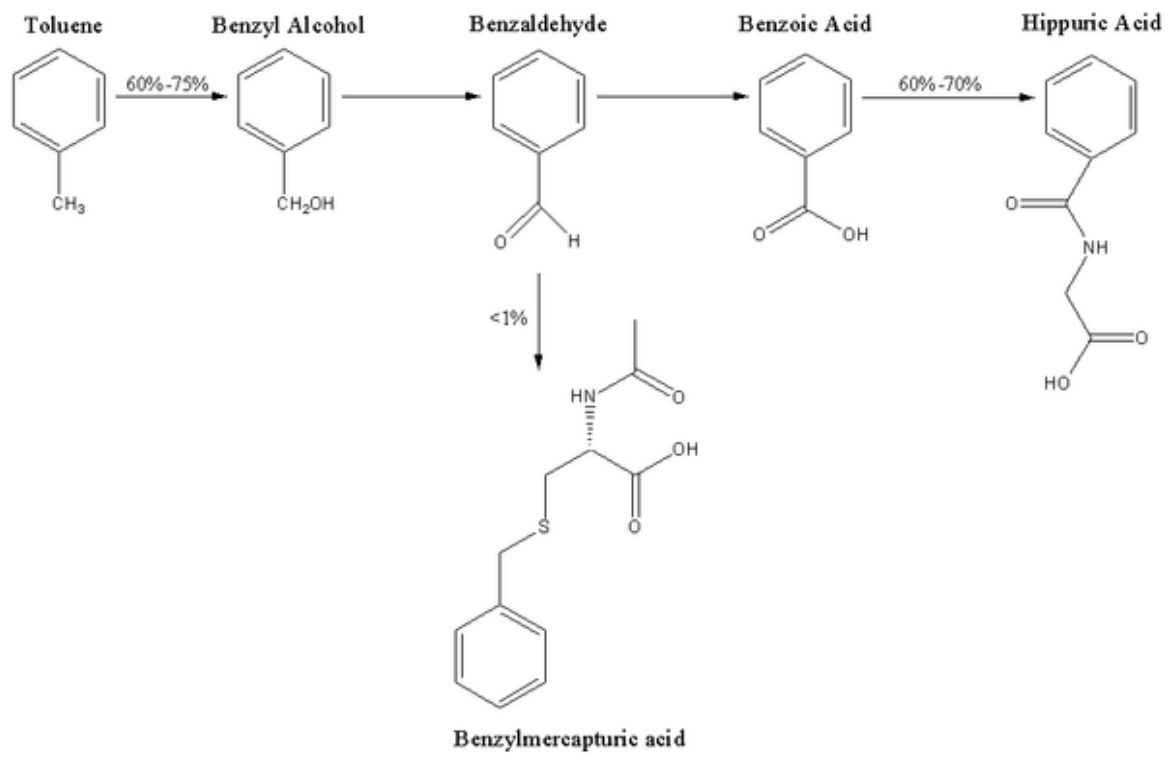

Scheme 3. Complete toluene metabolism in urine [47] 
According to the World Health Organization (WHO), following inhalation, toluene is predominantly excreted in the urine as the metabolite, hippuric acid. Approximately $7-20 \%$ of absorbed toluene is eliminated in air unchanged. Following a single acute exposure, toluene and its metabolites are almost completely eliminated within 24 hours [49].

Scheme 3 illustrates a full steps of toluene metabolism in urine. Approximately 60 to $75 \%$ toluene is converted to benzyl alcohol before further oxidized to benzaldehyde. Less than $1 \%$ benzaldehyde is converted to benzyl mercapturic acid while the rest is converted to benzoic acid. About 60 to $70 \%$ hippuric acid is produced from conjugating benzoic acid with glycine.

\section{Analytical methods: Sample collection and storage}

It is a good practice that biological specimens should be stored at $4{ }^{\circ} \mathrm{C}$ before transported to the laboratory. Exceptions to this include hair and nail, which are stable at room temperature and filter paper with adsorbed dried blood, which is a convenient way of storing and transporting blood samples for specified analyses whenever refrigerated transport and storage is not feasible [50].

Each specimen bottle should be securely sealed to prevent leakage and individually packaged in a separate plastic bag. Particular attention should be given to the packaging of the samples to be transported by post or courier in order to comply with current health and safety regulations. Sample volumes or amounts smaller than those indicated in Table 1 are often sufficient to complete the analyses required. However submission of very small sample may result in reduced sensitivity and scope of the analyses undertaken but nevertheless such samples should always be forwarded to the laboratory. Any residual specimen should be kept at $-20{ }^{\circ} \mathrm{C}$ or below until investigation of the incident has been concluded.

Table 1. Sample requirements for general analytical toxicology

\begin{tabular}{ll}
\hline Sample & \multicolumn{1}{c}{ Notes } \\
\hline Whole Blood & $10 \mathrm{~mL}$ (lithium heparin or EDTA tube - use fluoride/oxalate/citrate if ethanol is \\
& $\begin{array}{l}\text { suspected; plastic tube if paraquat is suspected; glass or plastic tube with } \\
\text { minimal headspace if carbon monoxide or other volatile is suspected) }\end{array}$ \\
& $5 \mathrm{~mL}$ (send whole blood if volatiles, metals and some other compounds are \\
Plasma/Serum & suspected) \\
& $20-50 \mathrm{~mL}$ (plain bottle, sodium fluoride) \\
Urine & $25-50 \mathrm{~mL}$ (plain bottle, no preservative) \\
Gastric contents & Vitreous humor (maximum available collect separately from both eyes), bile \\
Other samples & (2 mL) or liver (about 5g) can be a substitute for urine postmortem work. Other \\
& tissues (brain, liver, kidney, lung, and subcutaneous fat - 5g) may also be \\
& valuable, especially if organic solvents or other volatile poison is suspected. \\
\hline
\end{tabular}

\section{Preliminary Test}

Color tests are useful in minimizing the use of equipment and expertise required. However, the reagent has to be easily available and stable. Sensitivity is limited and the tests are usually applicable only to urine. It is possible to extract the metabolite and apply the color test to the residue, though this is rarely done for biological fluids. False negatives are a risk even when a test is used for its intended purposes in appropriate samples. Positive results with poison, metabolite or others serve to indicate the need for quantitative measurement. Urine samples are commonly used for preliminary test. This is because of urine is easy to collect and it can be useful to provide qualitative information about exposure to a particular substance (Table 2).

Researches in toluene exposure are extensive whether they involve quantitative or qualitative analyses. One of the most varied tools for qualitative analysis is a color test method. Many years ago, only a few of researchers 
employed color test method to determine toluene metabolites [51]. Among the metabolites of toluene, hippuric acid is a traditional biomarker for the biological monitoring of toluene exposure but both $o$-cresol and hippuric acid are used by the endogenous and dietary sources [52].

Table 2. Color test methods for determination of toluene metabolites in urine

\begin{tabular}{|c|c|c|c|c|c|}
\hline $\begin{array}{l}\text { Sample Pre- } \\
\text { treatment }\end{array}$ & Procedure $^{a}$ & Analysis Method & $\begin{array}{c}\text { Color } \\
\text { Changes }\end{array}$ & $\begin{array}{c}\text { Detection } \\
\text { Limit }\end{array}$ & Ref. \\
\hline $\begin{array}{l}\text { Extracted } \\
\text { three times } \\
\text { with methanol }\end{array}$ & $\begin{array}{l}\text { Detection of hippuric acid based upon } \\
\text { azlactone formation resulting from the } \\
\text { reaction of an aldehyde with hippuric } \\
\text { acid.Hippuric acid was converted to a } \\
\text { deep orange-colored azlactone, } 2- \\
\text { phenyl 4- (p-dimethylamino)benzal 5- } \\
\text { oxazolone, by treatment of hippuric acid } \\
\text { with acetic anhydride and p- } \\
\text { dimethylamino-benzaldehyde. }\end{array}$ & $\begin{array}{l}\text { Colorimetry } \\
\text { method. } \\
\lambda_{\max }=410 \mathrm{~nm}\end{array}$ & $\begin{array}{l}\text { Yellow to } \\
\text { deep orange } \\
\text { color. }\end{array}$ & N.R & [52] \\
\hline $\begin{array}{l}\text { Acid } \\
\text { extraction of } \\
\text { urine sample }\end{array}$ & $\begin{array}{l}0.5 \mathrm{~mL} \text { hippuric acid of pyridine (Pyr) } \\
\text { solution mixed to } 0.2 \mathrm{~mL} \text { of } \\
\text { benzenesulphonyl chloride (BSC). The } \\
\text { solution was allowed to stand }>20 \text { min. } \\
\text { It is then diluted to } 5 \mathrm{~mL} \text { with } \\
\text { chloroform and recorded at } 380 \mathrm{~nm} \text {. }\end{array}$ & $\begin{array}{l}\text { Colorimetry } \\
\text { method. } \\
\lambda_{\max }=420 \text { (red } \\
\text { color) and } 360 \mathrm{~nm} \\
\text { (orange color). }\end{array}$ & $\begin{array}{l}\text { Yellow to } \\
\text { orange red } \\
\text { color within } \\
40 \text { min. }\end{array}$ & $\begin{array}{c}0.135 \\
\mathrm{mg} / \mathrm{mL}\end{array}$ & [53] \\
\hline No extraction & $\begin{array}{l}0.5 \mathrm{~mL} \text { of urine and } 0.5 \mathrm{~mL} \text { of Pyr were } \\
\text { mixed and added with } 0.2 \mathrm{~mL} \text { of BSC } \\
\text { and mixed for } 5 \mathrm{~s} \text { with a vibration } \\
\text { mixer. The colored solution was } \\
\text { allowed to stand for } 30 \mathrm{~min} \text { at room } \\
\text { temperature, diluted to } 5 \mathrm{~mL} \text { with } \\
\text { ethanol and mixed. The solution was } \\
\text { centrifuged for } 5 \mathrm{~min} \text { to remove a little } \\
\text { turbidity. The absorbance was } \\
\text { determined at } 410 \mathrm{~nm} \text { in ethanol. }\end{array}$ & $\begin{array}{l}\text { Colorimetry } \\
\text { method. } \\
\lambda_{\max }=410 \mathrm{~nm}\end{array}$ & $\begin{array}{l}\text { Yellow to } \\
\text { deep red } \\
\text { color within } \\
20 \text { min. }\end{array}$ & $\begin{array}{c}0.20 \\
\mathrm{mg} / \mathrm{mL}\end{array}$ & [54] \\
\hline No extraction & $\begin{array}{l}\text { Urine sample }(0.1 \text { or } 0.2 \mathrm{~mL}) \text { was } \\
\text { mixed with } 0.25 \mathrm{~mL} \text { Pyr, and } \\
\text { subsequently with } 0.1 \mathrm{~mL} \text { BSC. Then, } \\
0.125,0.25,0.5 .1 .0 \text { or } 1.5 \mathrm{~mL} \text { ultra- } \\
\text { pure water was added. }\end{array}$ & $\begin{array}{l}\text { Colorimetry } \\
\text { method. } \\
\lambda_{\max }=410 \mathrm{~nm}\end{array}$ & $\begin{array}{l}\text { Yellow to } \\
\text { deep red }\end{array}$ & $\begin{array}{c}0.125 \\
\mathrm{mg} / \mathrm{ml}\end{array}$ & [55] \\
\hline No extraction & $\begin{array}{l}0.1 \mathrm{~mL} \text { of urine added with } 0.25 \mathrm{~mL} \text { Pyr } \\
\text { and } 0.1 \mathrm{~mL} \text { BSC and } 1.0 \mathrm{~mL} \text { distilled } \\
\text { water. }\end{array}$ & $\begin{array}{l}\text { Spectrophotomety } \\
\text { UV at } \lambda_{\max }=417 \\
\mathrm{~nm}\end{array}$ & $\begin{array}{l}\text { Yellow to } \\
\text { deep red } \\
\text { within } 1 \\
\text { min. }\end{array}$ & $\begin{array}{c}0.125 \\
\mathrm{mg} / \mathrm{ml}\end{array}$ & [11] \\
\hline
\end{tabular}

${ }^{\text {a }}$ Pyr, Pyridine; BSC, Benzenesulphonyl Chloride. N.R; Not reported.

Color test methods for hippuric acid have been developed since 1950s and further investigated by researchers in early 1980s. The founders of color reaction for hippuric acid, Gaffney et al. employed the formation of azlactone resulting from the reaction of an aldehyde with hippuric acid [51]. In this reaction, hippuric acid was converted to a deep orange colored azlactone, 2-phenyl-4-(p-dimethylamino) benzal-5-oxazolone by treatment of hippuric acid with acetic anhydride and p-dimethylaminobenzaldehyde. Urine sample was extracted three times with methanol for sample pre-treatment. The absorption was recorded with colorimetry method at $\lambda_{\max }=410 \mathrm{~nm}$. 
A few years later, Umberger and Fiorese found a new method using pyridine and benzenesulfonyl chloride to develop deep red color in the presence of hippuric acid. Urine sample was extracted using ethyl acetate before recording using colorimetric method at $\lambda_{\max }=420 \mathrm{~nm}$ (red) and $360 \mathrm{~nm}$ (orange) with detection limit of 0.135 $\mathrm{mg} / \mathrm{mL}$ [53]. An investigation using colorimetric method was also reported by Tomokuni and Ogata [54]. The procedure employed $0.5 \mathrm{~mL}$ of urine, $0.5 \mathrm{~mL}$ of pyridine and $0.2 \mathrm{~mL}$ of BSC that were mixed for about $5 \mathrm{~s}$ with a vibration mixer and the colored solution was allowed to stand for $30 \mathrm{~min}$ at room temperature and then diluted with $5 \mathrm{~mL}$ of ethanol. Then the solution was centrifuged for $5 \mathrm{~min}$ to remove a little turbidity and the absorbance was determined at $410 \mathrm{~nm}$ in ethanol. This spectrophotometer method was simple but the yellow coloration obtained was indistinguishable from the yellowish color of urine because of the ethanol dilution.

In 2005, Yoshida et al. [55] modified the color test method that was established by Umberger and Fiorese, [53]. It involves a new color test method where the addition of pyridine and benzenesulfonyl chloride with existing distilled water develops a deep red color in the presence of hippuric acid. The colorimetric method for urine hippuric acid investigated in this study is based on the color reaction (reddening) of the specimen, which can be judged more clearly than the method of Tomokuni and Ogata [54] which involves a change to yellowish color. This method required only several minutes and used only commercially-available reagents without any pre-treatment. This work demonstrated the color changed but they it did not illustrate the color changes with different concentrations of hippuric acid. Besides that, the work was only focused on samples of people exposed to toluene and did not provide the equation and reaction of the color test method [55].

More recently, Yacob and Zinalibdin, developed a simple mobile test kit for screening and detecting glue sniffers based on the color test method [11]. The results obtained using the kit is are similar to those using UV-Vis result but it technique is faster with the results obtained within only $5 \mathrm{~min}$ and is also comparable to the dip strip urine drug testing kits. Thus, this kit can be a fast and in situ tool to help the National Anti-Drug agency for in the screening and detecting glue abusers among school students and teenagers [11].

\section{Sample pre-treatment: Hippuric acid sample pre-treatment prior to HPLC}

Liquid-liquid extraction (LLE) has been used for sample pretreatment of toluene metabolites. Poggi et al. illustrated the extraction procedure was performed on acidified urine, after addition of 4-hydroxybenzoic acid as internal standard using a butylchloride/isopropanol mixture and $0.5 \mathrm{~mL}$ of the organic layer was dried under nitrogen flow. The residue obtained was dissolved in $0.1 \mathrm{~mL}$ water/acetonitrile and $5 \mu \mathrm{L}$ was injected into a HPLC [15]. Matsui et al. in his research used ethyl acetate for partial clean-up of biological samples [56]. Bevine et al. conducted a sample pretreatment which is made alkaline and extracted stepwise with methylene chloride and ethyl acetate and the addition of internal standard (3-methoxysalicylic acid) in plasma samples [57]. Meanwhile, several works have demonstrated sample pretreatments that do not require extraction step but effected only by dilution with distilled water followed by centrifugation [14, 58, 59].

Liquid-liquid-liquid microextraction (LLLME) method was developed for the determination of hippuric acid in urine and serum sample [60]. The analyte was extracted from an acidic aqueous sample solution ( $\mathrm{pH} 3)$ through a thin layer of organic solvent membrane and back-extracted to a basic acceptor drop ( $\mathrm{pH} 11)$ suspended on the tip of a 10- $\mu$ L HPLC syringe in organic layer. Green technology was adapted in this method that offers the advantages of being simple, sensitive and inexpensive.

A simple molecularly imprinted polymer coated with modifed polysulfone membrane was introduced by Moein et al. [61]. The membrane was utilized for online extraction of hippuric acid in biological matrices. This method provided fast, sensitive, selective and robust sample preparation method for hippuric acid in biological fluids.

\section{Hippuric acid sample pre-treatment and derivatization procedure prior to gas chromatography}

Methods for the determination of hippuric acid based on GC usually require a derivatization procedure in the sample pretreatment step. A number of researchers have established the derivatization procedure for the analysis of toluene metabolites. Some researchers used diazomethane but it is an explosive, carcinogenic and highly toxic reagent [62-64].Other researchers used expensive substances as reagents to obtain methylsilyl derivatives which 
require frequent cleaning of the GC detector $[65,66]$ and these derivatives are moisture-sensitive. In 1991, De Carvalho et al. [23] proposed the derivatization of hippuric acid using methanol in acid medium (HCl), a low-cost and low toxicity reagent. About ten years later, Kongtip et al. modified the method using a GC equipped with a DB1 capillary column and a flame ionization detector [25]. The method successfully separated and eluted methyl esters of hippuric acid, $o-, m$ - and $p$-methylhippuric acid within $11 \mathrm{~min}$.

Extraction step is often the first step for the detection of toluene metabolites using GC. Before this century, many researcher used LLE as extraction step where the sample was acidified with acid and then the analyte was extracted using ethyl acetate [23, 25, 62-64]. The organic layer was collected for the derivatization step.

A novel approach of the extraction of hippuric acid using solid phase extraction [67] has been introduced. In the approach, an online automatic method for extraction of hippuric acid from urine sample using $\mu$-solid phase extraction with polypyrrole adsorbent system was established [68]. However, post derivatization of hippuric acid by conversion to its methyl ester with methanol in hydrochloric acid was still needed for monitoring the toluene metabolites using GC.

\section{Cresol pre-treatment prior to gas chromatography}

The urinary cresol is present in urine sample usually as sulphate or glucuronic acid conjugates. For this reason, hydrolysis and neutralization steps are required to determine the urinary cresol. Truchon et al. in 1996 described a sensitive and reproducible gas chromatographic procedure for the determination of urinary $o$-cresol as follows. Acid hydrolysis was the first step encountered to produce unconjugated $o$-cresol. After extraction with methylene chloride at $\mathrm{pH} \mathrm{2,} \mathrm{the} \mathrm{organic} \mathrm{layer} \mathrm{was} \mathrm{concentrated} \mathrm{by} \mathrm{evaporation} \mathrm{and} \mathrm{the} \mathrm{sample} \mathrm{was} \mathrm{analyzed} \mathrm{by} \mathrm{GC-flame}$ ionization detection [27].

Solid phase microextraction (SPME) was established for determination of urinary $o$-cresol. Acid-hydrolyzed step is still required for the sample and a CW/DVB fiber was directly immersed in the sample solution for 20 min under magnetic stirring for the extraction. This SPME device was then introduced into chromatography injector port where the analyte is thermally desorbed from the fiber [26].

\section{Analysis by High Performance Liquid Chromatography}

Numerous sample pretreatment and HPLC methods have been proposed for the separation of toluene metabolites in biological samples, some of which are listed in Table 3. Several researchers have worked on the determination of hippuric acid in urine and blood samples. A few of them studied on the determination of hippuric acid in urine and blood for exposure of toluene, xylene and other chemicals for occupational and safety health. Ogata and his coworkers [59] determined hippuric acid as indicator of toluene exposure by HPLC. They used mixed solution of methanol-water-acetic acid (20: 80: 0.2) as the mobile phase and UV detection at $254 \mathrm{~nm}$ and without solvent extraction and pretreatment. Their results showed a low detection limit of $0.2 \mu \mathrm{g}$ and analysis time of $<30 \mathrm{~min}$.

HPLC method for simultaneous quantitative determination of the urinary metabolites of toluene, $\mathrm{m}$-xylene and styrene (hippuric acid, $m$ - methyl hippuric acid, phenylglyoxylic acid, mandelic acid) was described by Poggi et al. [15]. In the method, the residue obtained was dissolved in $0.1 \mathrm{~mL}$ of water/acetonitrile and $5 \mu \mathrm{L}$ of the solution was injected into a HPLC system for analysis. Absorbance measurement was performed at $225 \mathrm{~nm}$ using UV detector. All metabolites were clearly separated within 12 min [15].

The direct determination of hippuric acid (HA) and $o-, m$ - and $p$-methylhippuric acids (MHA) in the urine, metabolites of toluene and $o-, m$ - and $p$-xylenes by HPLC have been described and established. A mixed solution of methanol-water-acetic acid (80: 20: 0.2$)$ containing tetra- $n$-butylammonium bromide $(0.2 \% \mathrm{w} / \mathrm{v})$ as mobile phase was used. Concentrations of HA and MHAs were estimated from their peak height at a wave length of $225 \mathrm{~nm}$. Urine can be analyzed directly without solvent extraction or pretreatment to obtain complete separation of HA and $o-, m$ - and $p$-MHAs. Authentic samples of glycine conjugates, HA and $o-, m$ - and $p$-MHAs, in water and urine were well separated from each other and eluted within 25 min [69]. 
An automated HPLC method for the direct determination of urinary concentrations of hippuric acid (HA), and $o-$, $m$ - and $p$-methyl hippuric acids (MH As), metabolites of toluene and $o-, m$ - and $p$-xylenes, and of urinary phenyl glyoxylic acid (PGA) and mandelic acid (MA), metabolites of styrene or ethylbenzene have been described. Methanol was added to urine, the mixture was centrifuged and the supernatant was injected into HPLC A stainlesssteel column packed with octadecyl silanized silicate was used and the mobile phase was a mixture solution of 5 $\mathrm{mM}$ potassium phosphate monobasic-acetonitrile (90:10) The method is simple and specific. Urine can be analyzed without solvent extraction. Analysis can be performed satisfactorily within $45 \mathrm{~min}$ for samples containing HA, MHAs, PGA and MA, and within 15 min for those containing HA, PGA and MA [70].

Matsui et al. [56] used HPLC for the determination of hippuric acid in urine sample. The separation was carried out on a reversed-phase column using $20 \%$ methanol in $0.01 \mathrm{M}$ potassium phosphate containing $0.5 \%$ acetic acid as the mobile phase. The column effluent was monitored using UV detection at $254 \mathrm{~nm}$. Hipuric acid was separated from other normal urine constituents in less than $10 \mathrm{~min}$.

Kubota et al. [58] described the monitoring of hippuric acid and benzoic acid simultaneously in human biological fluids and considered it to be clinically important. They developed a simple and accurate HPLC method for the simultaneously determination of hippuric acid and benzoic acid in human urine and plasma. This research required no extraction step. Aliquots of urine and plasma were added to a solution of internal standard (o-chlorobenzoic acid) in acetonitrile and directly injected into a HPLC system using an acidic ( $\mathrm{pH} 2.7)$ eluent and UV detection at $235 \mathrm{~nm}$.

A method has been developed for the isocratic HPLC analysis of hippuric acid in human blood plasma. After the addition of internal standard (3-methoxysalicylic acid), plasma samples were made alkaline and extracted stepwise using methylene chloride and ethyl acetate. The detection limit was $50 \mathrm{pmol}$ of hippuric acid per $\mathrm{mL}$ plasma. This work was conducted on samples from human occupationally exposed to organic solvent as described by Bevine et al. [57].

A simple HPLC procedure was described as a method for simultaneous determination of the six metabolites in urine namely hippuric acid , $o-, m$ - and $p$-methylhippuric acid, phenylglyoxylic acid and mandelic acid. Urine analysis was selected in the study because of its non-invasive nature in sampling with minimal burden on exposed workers. A mobile phase of methanol-acetic acid-water (200: 8: 792) by volume was allowed to flow at a rate of 0.85 $\mathrm{mL} / \mathrm{min}$ and monitored at a wavelength of $257 \mathrm{~nm}[13]$.

Yang [14] described a simple method for the simultaneous determination of creatine, uric acid, creatinine and hippuric acid in urine using HPLC. Chromatography was performed with a $0.02 \mathrm{M} \mathrm{KH}_{2} \mathrm{PO}_{4}$ as a mobile phase and UV detection at $220 \mathrm{~nm}$ without any extraction method. This method was applied for biomedical application to analyze urine samples from normal subjects and some patients. A HPLC method for determination of hippuric acid in urine was described by Yoshida et al. [55]. The mobile phase was $30 \%$ methanol containing $0.1 \%$ acetic acid and UV detection at $225 \mathrm{~nm}$. No extraction method was used in this work. Urine samples were centrifuged (12 $000 \mathrm{rpm}$, $10 \mathrm{~min}$ ) and $5 \mu \mathrm{L}$ supernatant was injected for analysis. This method was applied to the analysis of glue sniffer's urine [55].

A simple method for the simultaneous determination of hippuric acid and benzoic acid in urine using reversed-phase HPLC was described by Yacob and Zinalibdin [71]. Chromatography was performed with a mobile phase of mixed solution methanol-water-acetic acid (20: 80: 0.2) and UV detection at $254 \mathrm{~nm}$ in $<10 \mathrm{~min}$. The detection limit of this method was $0.01 \mathrm{mg} / \mathrm{L}$ for hippuric acid and $0.06 \mathrm{mg} / \mathrm{L}$ for benzoic acid. This method was applied to the analysis of urine samples from the suspected of toluene abuser or glue sniffer among secondary school students. Meanwhile, Lee et al. [18] developed a simple and rapid HPLC-UV method for the simultaneous determination of eight urinary metabolites which is hippuric acid, mandelic acid, $o-, m$ - and $p$-methylhippuric acid and $o-, m$ - and $p$ cresols. All eight metabolites were successfully resolved within $5 \mathrm{~min}$ in $10 \%$ aqueous ethanol containing $0.3 \%$ acetic acid and $1.6 \% \beta$-cyclodextrin, using a gradient flow rate $1.0-5.0 \mathrm{~mL} / \mathrm{min}[18]$. 
Mohamad Raizul et al: CHROMATOGRAPHIC DETERMINATION OF TOLUENE AND ITS METABOLITES

IN URINE FOR TOLUENE EXPOSURE - A REVIEW

Table 3. Conditions for sample pretreatment and HPLC separation of toluene metabolites in biological samples

\begin{tabular}{|c|c|c|c|c|c|c|}
\hline $\begin{array}{l}\text { Sample Pre- } \\
\text { treatment }^{\mathrm{a}}\end{array}$ & $\begin{array}{l}\text { HPLC } \\
\text { Column }\end{array}$ & $\begin{array}{l}\text { Detection } \\
\text { Limit }^{\mathrm{b}}\end{array}$ & Mobile Phase $^{c}$ & $\begin{array}{l}\text { Detection } \\
\text { wavelength }\end{array}$ & $\begin{array}{l}\text { Target } \\
\text { Analyte }^{\mathrm{d}}\end{array}$ & Ref. \\
\hline $\begin{array}{l}\text { Acidified urine } \\
\text { sample and } \\
\text { extracted with } \\
\text { ethyl acetate by } \\
\text { shaking. } \\
\text { Centrifuge for } 5 \\
\text { min at } 1000 \mathrm{rpm} \text {. }\end{array}$ & $\begin{array}{l}\text { Bondapak } \\
\text { C18 } \\
(30 \mathrm{~cm} \times 4 \\
\mathrm{mm}) \\
\text { Flow rate : } \\
0.70 \mathrm{~mL} / \mathrm{min} \\
\text { Time }: 11 \mathrm{~min}\end{array}$ & N.R & $\begin{array}{l}20 \% \mathrm{MeOH}_{\text {in }} \\
0.01 \mathrm{M} \mathrm{K}_{2} \mathrm{PO}_{4} \\
\text { containing } 0.5 \% \\
\text { v/v HOAC. }\end{array}$ & $254 \mathrm{~nm}$ & HA & [56] \\
\hline $\begin{array}{l}\text { Acidified urine, } \\
\text { add } 4- \\
\text { hydroxybenzoic } \\
\text { acid using } \\
\text { butylchloride/IPA } \\
\text { and dried with } \\
\mathrm{N}_{2} . \text { Residue } \\
\text { dissolve in } 0.1 \\
\mathrm{~mL} \text { water } \\
\text { /acetonitrile. }\end{array}$ & $\begin{array}{l}\text { HC ODS Sil- } \\
\mathrm{X} \\
\text { Flow rate: } 1.0 \\
\mathrm{~mL} / \mathrm{min} \\
\text { Time: } 12 \mathrm{~min}\end{array}$ & $\begin{array}{l}\text { MA: } 25 \mu \mathrm{g} / \mathrm{mL} \\
\text { HA: } 7.5 \mu \mathrm{g} / \mathrm{mL} \\
\text { m-mHA: } \\
10 \mu \mathrm{g} / \mathrm{mL} \\
\text { PHGA: } 1 \mu \mathrm{g} / \mathrm{mL}\end{array}$ & $\begin{array}{l}\text { Water: ACN: } \\
\text { HOAC } \\
\text { 95: 5: } 0.02\end{array}$ & $225 \mathrm{~nm}$ & $\begin{array}{l}\text { MA, HA, } \\
\text { m-mHA, } \\
\text { PHGA. }\end{array}$ & [15] \\
\hline $\begin{array}{l}1 \mathrm{ml} \mathrm{MeOH} \text { mix } \\
\text { with } 1 \mathrm{~mL} \text { urine } \\
\text { and centrifuge at } \\
2000 \mathrm{rpm} \text { for } 5 \\
\text { min. }\end{array}$ & $\begin{array}{l}\text { Silica gel } \\
\text { Flow rate: } 1.2 \\
\text { mL/min. } \\
\text { Time: } 25 \text { min }\end{array}$ & N.R & $\begin{array}{l}\text { MeOH-water- } \\
\text { HOAC } \\
\text { 80: } 20: 0.2 \\
\text { With tetra- } n \text {-butyl } \\
\text { ammonium } \\
\text { bromide } 0.2 \% \\
\text { w/v }\end{array}$ & $225 \mathrm{~nm}$ & $\begin{array}{l}\text { HA, o- } \\
\text { mHA, m- } \\
\text { mHA }\end{array}$ & [69] \\
\hline $\begin{array}{l}\text { Urine dilute with } \\
\text { mobile phase and } \\
\text { centrifuge at } \\
2000 \text { rpm for } 5 \\
\text { min. }\end{array}$ & $\begin{array}{l}\text { Octadecyl- } \\
\text { silanized } \\
\text { silica gel } \\
(0.4 \mathrm{~mm} \times \\
150 \mathrm{~mm}) \\
\text { Flow rate: } 0.7 \\
\mathrm{~mL} / \mathrm{min} \\
\text { Time: } 20 \mathrm{~min}\end{array}$ & $\begin{array}{l}\text { MA: } 5 \mathrm{ng} / \mathrm{mL} \\
\text { HA: } 2 \mathrm{ng} / \mathrm{mL} \\
\text { o-mHA: } 4 \\
\text { ng/mL } \\
\text { m-mHA : } \\
\text { 4ng/mL } \\
\text { PHGA: } 1 \\
\text { ng/mL }\end{array}$ & $\begin{array}{l}0 \mathrm{mM} \quad \mathrm{KH}_{2} \mathrm{PO}_{4} \\
(\mathrm{pH} 3.3) \\
\text { containing } 3 \mathrm{mM} \\
\text { 1-decane- } \\
\text { sulfonate } / \mathrm{CH}_{3} \mathrm{CN} \\
(85: 15)\end{array}$ & $225 \mathrm{~nm}$ & $\begin{array}{l}\text { HA, o- } \\
\text { mHA, } \\
\text { MA, } \\
\text { Creatinine }\end{array}$ & [70] \\
\hline $\begin{array}{l}100 \mu 1 \text { sample mix } \\
\text { with } 200 \mu 1 \\
\text { contain ISTD }\end{array}$ & $\begin{array}{l}\text { Yanapak } \\
\text { ODSA } \\
(250 \mathrm{~mm} \times \\
4.6 \mathrm{~mm}) \\
\text { Flow rate: } 1.0 \\
\mathrm{~mL} / \mathrm{min} \\
\text { Time: } 10 \mathrm{~min}\end{array}$ & $\begin{array}{l}\text { BA \& HA: } \\
1 \mu \mathrm{g} / \mathrm{mL}\end{array}$ & $\begin{array}{l}\text { CAN-water- } \\
\text { HOAC } \\
\text { 35:63: } 2\end{array}$ & $235 \mathrm{~nm}$ & HA \& BA & $58]$ \\
\hline
\end{tabular}


Table 3 (cont'd). Conditions for sample pretreatment and HPLC separation of toluene metabolites in biological samples

\begin{tabular}{|c|c|c|c|c|c|c|}
\hline $\begin{array}{l}\text { Sample Pre- } \\
\text { treatment }^{\mathrm{a}}\end{array}$ & $\begin{array}{l}\text { HPLC } \\
\text { Column }\end{array}$ & $\begin{array}{l}\text { Detection } \\
\text { Limit }^{\mathrm{b}}\end{array}$ & Mobile Phase $^{c}$ & $\begin{array}{l}\text { Detection } \\
\text { wavelength }\end{array}$ & $\begin{array}{l}\text { Target } \\
\text { Analyte }^{\mathrm{d}}\end{array}$ & Ref. \\
\hline $\begin{array}{l}\text { Urine mix with } \\
\text { MeOH and } \\
\text { centrifuge } 1600 \\
\text { rpm at } 60 \text { min }\end{array}$ & $\begin{array}{l}\text { Intersil ODS- } \\
2 \\
(4.6 \mathrm{~mm} \times \\
250 \mathrm{~mm}) \\
\text { Flow rate: } \\
0.85 \mathrm{~mL} / \mathrm{min} \\
\text { Time: } 20 \mathrm{~min}\end{array}$ & $\begin{array}{l}\text { HA: } 0.5 \mathrm{mg} / \mathrm{L} \\
\text { o-mHA: } \\
\text { 2.0mg/L } \\
\text { m-mHA: } 0.8 \\
\text { mg/L } \\
\text { p-mHA: } 0.2 \\
\text { mg/L } \\
\text { PHGA: } 0.1 \\
\text { mg/L } \\
\text { MA: } 3 \text { mg/L }\end{array}$ & $\begin{array}{l}\text { MeOH-HOAC- } \\
\text { water } \\
\text { 200: } 8: 792\end{array}$ & $257 \mathrm{~nm}$ & $\begin{array}{l}\text { MA, HA, } \\
\text { o-mHA, p- } \\
\text { mHA, m- } \\
\text { mHA, } \\
\text { PHGA. }\end{array}$ & [13] \\
\hline N.R & $\begin{array}{l}\text { Novapak- C18 } \\
(3.9 \mathrm{~mm} \times \\
150 \mathrm{~mm}) \\
\text { Flow rate: } 0.5 \\
\mathrm{~mL} / \mathrm{min} \\
\text { Time: } 10 \mathrm{~min}\end{array}$ & & $\begin{array}{l}0.02 \mathrm{~mol} / \mathrm{L} \\
\mathrm{KH} 2 \mathrm{PO} 4\end{array}$ & $220 \mathrm{~nm}$ & $\begin{array}{l}\text { Creatine, } \\
\text { Uric acid, } \\
\text { Creatinine, } \\
\text { HA }\end{array}$ & [14] \\
\hline $\begin{array}{l}2 \mathrm{~mL} \text { of urine } \\
\text { centrifuge at } \\
12000 \mathrm{rpm} \text { for } 10 \\
\text { min. }\end{array}$ & $\begin{array}{l}\text { Devolosil C18 } \\
(15 \mathrm{~cm} \times 4.6 \\
\mathrm{mm}) \\
\text { Flow rate: } \\
0.70 \mathrm{~mL} / \mathrm{min}\end{array}$ & HA: $0.1 \mathrm{ng} / \mathrm{mL}$ & $\begin{array}{l}\text { MeOH-water- } \\
\text { HOAC } \\
\text { 20: } 80: 0.2\end{array}$ & $254 \mathrm{~nm}$ & HA & [55] \\
\hline $\begin{array}{l}\text { Acidified urine } \\
\text { and extracted } \\
\text { with diethyl } \\
\text { eter/methanol } \\
(9: 1)\end{array}$ & $\begin{array}{l}\text { Novapak-C18 } \\
(3.9 \mathrm{~mm} \times \\
150 \mathrm{~mm}) \\
\text { Flow rate: } 1.0 \\
\mathrm{~mL} / \mathrm{min} \\
\text { Time: } 8 \mathrm{~min}\end{array}$ & $\begin{array}{l}\mathrm{HA}: 0.01 \mathrm{mg} / \mathrm{L} \\
\text { BA: } 0.06 \mathrm{mg} / \mathrm{L}\end{array}$ & $\begin{array}{l}\text { MeOH-water- } \\
\text { HOAC } \\
\text { 20: } 80: 0.2\end{array}$ & $254 \mathrm{~nm}$ & $\mathrm{HA} \& \mathrm{BA}$ & [71] \\
\hline
\end{tabular}


Table 3 (cont'd). Conditions for sample pretreatment and HPLC separation of toluene metabolites in biological samples

\begin{tabular}{|c|c|c|c|c|c|c|}
\hline $\begin{array}{l}\text { Sample Pre- } \\
\text { treatment }^{\mathrm{a}}\end{array}$ & $\begin{array}{l}\text { HPLC } \\
\text { Column }\end{array}$ & $\begin{array}{l}\text { Detection } \\
\text { Limit }^{\mathrm{b}}\end{array}$ & Mobile Phase ${ }^{c}$ & $\begin{array}{l}\text { Detection } \\
\text { wavelength }\end{array}$ & $\begin{array}{l}\text { Target } \\
\text { Analyte }^{\mathrm{d}}\end{array}$ & Ref. \\
\hline $\begin{array}{l}\text { Vortex sample } \\
\text { and ISTD. Dillute } \\
\text { with } 20 \text { fold } \\
\text { deionized water } \\
\text { and centrifuge for } \\
5 \text { min. }\end{array}$ & $\begin{array}{l}\text { Onyx } \\
\text { Monolith RP- } \\
18 \\
(4.6 \mathrm{~mm} \times \\
100 \mathrm{~mm}) \\
\text { Flow rate } \\
\text { gradient: } 1.0- \\
5.0 \mathrm{~mL} / \mathrm{min} \\
\text { Time: } 6 \mathrm{~min}\end{array}$ & $\begin{array}{l}\mathrm{HA}: 2 \mu \mathrm{g} / \mathrm{mL} \\
\text { MA: } 0.8 \mu \mathrm{g} / \mathrm{mL} \\
\text { o,m,p-mHA: } \\
0.4 \mu \mathrm{g} / \mathrm{mL} \\
\text { o, m, p-cresol: } \\
0.8 \mu \mathrm{g} / \mathrm{mL}\end{array}$ & $\begin{array}{l}\text { EtOH-HOAC- } \\
1.6 \% \beta- \\
\text { cyclodextrin } \\
10: 0.3: 90\end{array}$ & $225 \mathrm{~nm}$ & $\begin{array}{l}\text { HA, MA, } \\
\text { o,m,p- } \\
\text { mHA, o, } \\
\text { m, p- } \\
\text { cresol }\end{array}$ & [18] \\
\hline
\end{tabular}

a IPA, Isopropanol; $\mathrm{N}_{2}$, Nitrogen; $\mathrm{MeOH}$, Methanol; ISTD, Internal Standard.

${ }^{\mathrm{b}}$ NR, not recorded; MA, mandalic acid; HA, Hippuric acid; BA, Benzoic acid; o-mHA, o-methylhippuric acid; p-mHA, pmethylhippuric acid; m-mHA, m-methylhippuric acid, PHGA, phenylglyoxylic acid; o, ortho; p, para; m, meta.

${ }^{c} \mathrm{MeOH}$, methanol; $\mathrm{K}_{2} \mathrm{PO}_{4}$, Potassium phosphate; $\mathrm{HOAC}$, acetic acid; $\mathrm{ACN}$, acetonitrile; $\mathrm{KH}_{2} \mathrm{PO}_{4}$, Potassium dihydrogen phosphate; EtOH, ethanol.

${ }^{d}$ MA, mandalic acid; HA, Hippuric acid; BA, Benzoic acid; o-mHA, o-methylhippuric acid; p-mHA, p-methylhippuric acid; mmHA, m-methylhippuric acid, PHGA, phenylglyoxylic acid; o, ortho; p, para; m, meta.

\section{Analysis of VOCs by gas chromatography}

Gas chromatography (GC) offers some advantages for determination of volatile substances such as toluene due to its easy procedure. Selected examples of conditions for sample pretreatment and GC separation of toluene metabolite in biological sample are listed in Table 4. Head space method can achieve good separation of volatile solvents from the biological matrix [22]. In addition, the determination of toluene and its metabolites was not a problem as the GC peaks were well separated [21].

De Carvalho in his work [23] described the determination of hippuric acid by GC-flame ionization detection. This research proposed the derivatization of hippuric acid using methanol in acid medium which is a low cost reagent with a low level of toxicity. After the extraction procedure, hippuric acid and internal standard were converted to the methyl esters using methanol in acid medium. All methyl ester were detected in < $45 \mathrm{~min}$ [23]. Besides that, a sensitive and reproducible GC procedure for the quantitative determination of urinary o-cresol was also described [27]. The first step involves acid hydrolysis $\left(2 \mathrm{~N} \mathrm{HCl}, 100{ }^{\circ} \mathrm{C}, 10 \mathrm{~min}\right)$ which yields unconjugated $o$-cresol. After extraction (methylene chloride, $\mathrm{pH}$ 2), the organic layer is concentrated by evaporation and samples are analyzed by GC-flame ionization detection with a DB-5 column. The detection limit of the method is $0.36 \mu \mathrm{mol} / \mathrm{L}$ [27].

Determination of hippuric acid and $o-, m$ - and $p$-methylhippuric acid in urine was described by Kongtip et al. [25]. These metabolites were extracted using ethyl acetate and then derivatized it to methyl ester derivatives and quantitated using a gas chromatography flame ionization detector and DB-1 capillary column. The derivative of hippuric acid and $o-, m$ - and $p$-methylhippuric acid were well separated within $11 \mathrm{~min}$ [25].

Simultaneous determination of hippuric acid, $o-, m$ - and $p$-methylhippuric acids, mandelic acid and phenyl glyoxylic acid was developed and described by Ohashi et al. and it proved to be a fast and sensitive technique [72]. These metabolites were converted to methyl esters derivatives using methanol in hydrochloric acid and then quantitated by gas chromatography-mass spectrometry (GC-MS) with selected ion monitoring using a DB-1 capillary column. The target analytes were quantitatively analyzed and resolved within 19 min with low detection limit. 
Table 4. Conditions for sample pretreatment and GC separation of toluene metabolites in biological sample

\begin{tabular}{|c|c|c|c|c|c|c|}
\hline Sample Pre-treatment ${ }^{a}$ & $\begin{array}{l}\text { GC } \\
\text { Procedure }^{\text {b }}\end{array}$ & $\begin{array}{l}\text { Target } \\
\text { Analyte }^{\mathrm{c}}\end{array}$ & $\begin{array}{l}\text { Derivatization } \\
\text { Reagent }^{\mathrm{d}}\end{array}$ & $\begin{array}{l}\text { GC } \\
\text { Temperature }\end{array}$ & $\begin{array}{l}\text { Detection } \\
\text { Limit }^{\mathrm{f}}\end{array}$ & Ref. \\
\hline $\begin{array}{l}\text { Urine was acidified with } 0.5 \\
\mathrm{~N} \mathrm{HCl} \text { and extracted with } \\
\text { ethyl acetate } 20 \mathrm{~min} \text { in } \\
\text { horizontal shaker. Sample } \\
\text { was centrifuged at } 4000 \mathrm{rpm} \\
\text { for } 4 \text { min and organic phase } \\
\text { was collected. }\end{array}$ & $\begin{array}{l}\text { SE-30 in } \\
\text { Chromosorb } \\
\text { W-Silanized } \\
\text { glass } \\
\text { column } \\
\text { using GC- } \\
\text { FID }\end{array}$ & $\begin{array}{l}\text { PGHA, } \\
\text { OA, } o- \\
\text { mHA, } p \text { - } \\
\text { mHA, BA, } \\
\text { SA, MA, } \\
m \text {-cresol }\end{array}$ & $\begin{array}{l}\mathrm{MeOH} \text { in } \mathrm{HCl} \\
\text { medium. }\end{array}$ & $\begin{array}{l}\text { Carrier } \mathrm{N}_{2}: 40 \\
\mathrm{~mL} / \mathrm{min}-\mathrm{TPGC} \\
\text { Oven : } 200{ }^{\circ} \mathrm{C} \\
\text { Injector: } 240{ }^{\circ} \mathrm{C} \\
\text { Detector: } 240 \\
{ }^{\circ} \mathrm{C}\end{array}$ & N.R & [23] \\
\hline $\begin{array}{l}\text { Hydrolyzed }(2 \mathrm{~N} \mathrm{HCl}, \\
\left.100^{\circ} \mathrm{C}, 10 \mathrm{~min}\right) \text { and } \\
\text { extracted with methylene } \\
\text { chloride, } \mathrm{pH} 2 . \text { Organic } \\
\text { layer evaporated and } \\
\text { collected }\end{array}$ & $\begin{array}{l}\text { DB 5- } \\
\text { column } \\
\text { using GC- } \\
\text { FID }\end{array}$ & o-cresol & $\begin{array}{l}\text { Hydrolyzed } \\
\text { using } \mathrm{HCl} \text { and } \\
\text { incubated in } \\
\text { oven at } 100^{\circ} \mathrm{C} \\
\text { for } 10 \mathrm{~min} .\end{array}$ & $\begin{array}{l}\text { Carrier } \mathrm{N}_{2}: 40 \\
\mathrm{~mL} / \mathrm{min} \\
\mathrm{TPGC} \\
30^{\circ} \mathrm{C} \text { for } 12 \\
\text { min and then } \\
\text { increased } \\
2^{\circ} \mathrm{C} / \text { min to } 93 \\
{ }^{\circ} \mathrm{C}\end{array}$ & $\begin{array}{l}\text { o-cresol: } \\
0.36 \\
\mu \mathrm{mol} / \mathrm{L}\end{array}$ & [27] \\
\hline $\begin{array}{l}1 \mathrm{~mL} \text { of urine mix with } 1 \\
\mathrm{~mL} \text { distilled water and } \\
\text { acidified with } 0.5 \mathrm{M} \mathrm{HCl} \\
\text { then extracted with } 3 \mathrm{~mL} \\
\text { ethyl acetate. Sample was } \\
\text { evaporated to dryness and } \\
\text { the residue reconstituted } \\
\text { with derivatizing reagent } \\
\text { and left in oven at } 60^{\circ} \mathrm{C} \text { for } \\
45 \text { min. Solution was } \\
\text { extracted with } 1 \mathrm{~mL} \\
\text { chloroform and add } 2 \mathrm{~mL} \\
\text { distilled water. }\end{array}$ & $\begin{array}{l}\text { DB 1- } \\
\text { column } \\
\text { using GC- } \\
\text { FID }\end{array}$ & $\begin{array}{l}\mathrm{HA}, o, m, p- \\
\mathrm{mHA}\end{array}$ & $\begin{array}{l}\mathrm{MeOH} \text { in } \mathrm{HCl} \\
\text { medium. }\end{array}$ & $\begin{array}{l}\text { Carrier He: } 10 \\
\mathrm{~mL} / \mathrm{min} \\
\text { Isothermal } \\
\text { programmed } \\
\text { Oven : } 200^{\circ} \mathrm{C} \\
\text { Injector: } 250^{\circ} \mathrm{C} \\
\text { Detector: } 250 \\
{ }^{\circ} \mathrm{C}\end{array}$ & $\begin{array}{l}\text { HA: } 0.05 \\
\mathrm{mg} / \mathrm{mL} \\
\mathrm{o}, \mathrm{m}, \mathrm{p}-\mathrm{HA}: \\
0.015 \\
\mathrm{mg} / \mathrm{mL}\end{array}$ & {$[25]$} \\
\hline $\begin{array}{l}\text { Acidified and extracted with } \\
\text { diethyl ether. Sample was } \\
\text { centrifuged at } 2500 \mathrm{rpm} \text { for } \\
10 \text { min and dry incubated at } \\
70^{\circ} \mathrm{C} \text { for } 15 \text { min. Next } \\
\text { derivatize step was take } \\
\text { part. }\end{array}$ & $\begin{array}{l}\text { DB1- } \\
\text { column } \\
\text { using GC- } \\
\text { MS. } \\
\text { MA-mz:107 } \\
\text { PHGA-mz: } \\
\text { 105 } \\
\text { HA-mz: } 105 \\
o, p, m-m H A- \\
\text { mz: } 119\end{array}$ & $\begin{array}{l}\text { HA, } \\
\text { o,m,p- } \\
\text { mHA, } \\
\text { MA, } \\
\text { PHGA. }\end{array}$ & $\begin{array}{l}\mathrm{MeOH} \text { in } \mathrm{HCl} \\
\text { medium. }\end{array}$ & $\begin{array}{l}\text { Carrier He: } 1.8 \\
\mathrm{~mL} / \mathrm{min} \text { TPGC } \\
150{ }^{\circ} \mathrm{C} \text { for } 3 \\
\mathrm{~min} \text { at } 10 \\
{ }^{\circ} \mathrm{C} / \mathrm{min} \text { and } \\
\text { then increased } \\
250^{\circ} \mathrm{C} \text { for } 7 \\
\mathrm{~min} \text { at } 10^{\circ} \\
\mathrm{C} / \text { min } \\
\text { Injector: } 260^{\circ} \mathrm{C} \\
\text { Detector: } 260 \\
{ }^{\circ} \mathrm{C}\end{array}$ & $\begin{array}{l}\text { HA, } \\
\text { o,m,p- } \\
\text { mHA, } \\
\text { MA, } \\
\text { PHGA : 8- } \\
27 \text { pg/L }\end{array}$ & [72] \\
\hline
\end{tabular}


Table 4 (cont'd). Conditions for sample pretreatment and GC separation of toluene metabolites in biological sample

\begin{tabular}{|c|c|c|c|c|c|c|}
\hline Sample Pre-treatment ${ }^{\mathrm{a}}$ & $\begin{array}{l}\text { GC } \\
\text { Procedure }^{b}\end{array}$ & $\begin{array}{l}\text { Target } \\
\text { Analyte }^{\mathrm{c}}\end{array}$ & $\begin{array}{l}\text { Derivatization } \\
\text { Reagent }^{\mathrm{d}}\end{array}$ & $\begin{array}{l}\text { GC } \\
\text { Temperature }\end{array}$ & $\begin{array}{l}\text { Detection } \\
\text { Limit }^{\mathrm{f}}\end{array}$ & Ref. \\
\hline $\begin{array}{l}\text { Acidified using } \mathrm{HCl} \text { and } \\
\text { kept in oven at } 100^{\circ} \mathrm{C} \text { for } 1 \\
\text { h. Hydrolyzed and adjusted } \\
\text { pH } 7 \text { with } \mathrm{NaOH} \& \mathrm{Na}_{2} \mathrm{SO}_{4} \text {. } \\
\text { Immersed with } \mathrm{CW} / \mathrm{DVB} \\
\text { for } 20 \text { min under magnetic } \\
\text { stirrer. }\end{array}$ & $\begin{array}{l}\text { ZB-35 } \\
\text { column using } \\
\text { GC-FID }\end{array}$ & o-cresol & $\begin{array}{l}\text { Hydrolyzed } \\
\text { using } \mathrm{HCl} \text { and } \\
\text { kept in oven at } \\
100^{\circ} \mathrm{C} \text { for } 1 \\
\text { hour. }\end{array}$ & $\begin{array}{l}\text { Carrier } \mathrm{N}_{2}: 8.0 \\
\mathrm{~mL} / \mathrm{min} \\
\text { Isothermal } \mathrm{GC} \\
\text { Oven: } 190^{\circ} \mathrm{C} \\
\text { Injector: } 210^{\circ} \mathrm{C} \\
\text { Detector: } 220^{\circ} \mathrm{C}\end{array}$ & $\begin{array}{l}\text { o-cresol: } \\
0.1 \mathrm{mg} / \mathrm{L}\end{array}$ & [26] \\
\hline $\begin{array}{l}\text { DI-SPME directly immersed } \\
\text { in } 10 \mathrm{~mL} \text { vial for } 20 \mathrm{~min} \text { at } \\
60^{\circ} \mathrm{C} \text { and under agitation for } \\
20 \mathrm{~min} \text {. }\end{array}$ & $\begin{array}{l}\text { SLB-5 MS } \\
\text { using GC-MS }\end{array}$ & $\begin{array}{l}\text { FA, HA, } \\
\text { m- } \\
\text { mHA, } \\
\text { MA, } \\
\text { PGHA, } \\
\text { SA trans } \\
\text { muconic } \\
\text { acid }\end{array}$ & $\begin{array}{l}\text { Terimethyl- } \\
\text { oxonium } \\
\text { tetrafluoro- } \\
\text { borate }\end{array}$ & $\begin{array}{l}\text { Carrier He: } 1.2 \\
\mathrm{~mL} / \mathrm{min} \\
\mathrm{TPGC} 50{ }^{\circ} \mathrm{C} \\
(1 \mathrm{~min}) ; \\
\text { increased at } 10 \\
{ }^{\circ} \mathrm{C} / \mathrm{min} \text { to } 300 \\
{ }^{\circ} \mathrm{C}(3 \text { min }) .\end{array}$ & $\begin{array}{l}\text { FA: } \\
0.9 \mu \mathrm{g} / \mathrm{mL}, \\
\text { SA: } 8.1 \\
\mu \mathrm{g} / \mathrm{mL}, \mathrm{t}, \mathrm{t}- \\
\text { MA: } 0.9 \\
\mu \mathrm{g} / \mathrm{mL} .\end{array}$ & [24] \\
\hline $\begin{array}{l}\text { Centrifuge urine at } 4500 \\
\text { rpm for } 10 \text { min. } \mu \text {-SPE } \\
\text { system condition with } 2.0 \\
\mathrm{~mL} \mathrm{MeOH} \text { and } 3.0 \mathrm{~mL} \text { of } \\
\text { Britton-Robinson buffer }(3.0 \\
\left.\times 10^{-3} \mathrm{~mol} / \mathrm{L}, \mathrm{pH} 2\right) .0 .1 \mathrm{~mL} \\
\text { aliquot sample dilute with } \\
\text { Britton Robinson buffer at } \\
10 \mathrm{~mL} \text { volumetric flask. } \\
\text { Preconditioned catridge } 20 \\
\text { mg polypyrrole and washed } \\
\text { with Britton Robinson } \\
\text { buffer. }\end{array}$ & $\begin{array}{l}\text { CP Sil } 8 \text { CB } \\
\text { using GC- } \\
\text { FID }\end{array}$ & $\begin{array}{l}\text { HA in } \\
\text { urine } \\
\text { and } \\
\text { water }\end{array}$ & $\begin{array}{l}\mathrm{MeOH} \text { in } \mathrm{HCl} \\
\text { medium. }\end{array}$ & $\begin{array}{l}\text { Carrier He: } 10 \\
\text { psi. TPGC. } 80 \\
{ }^{\circ} \mathrm{C}(1 \mathrm{~min}) \text { at } \\
20^{\circ} \mathrm{C} / \mathrm{min} \text { to } \\
140^{\circ} \mathrm{C} \text { hold for } \\
1 \mathrm{~min} \text { at } \\
20^{\circ} \mathrm{C} / \mathrm{min} \text { then } \\
\text { increased } 280^{\circ} \mathrm{C} \\
(10 \text { min). } \\
\text { Injector: } 280^{\circ} \mathrm{C} \\
\text { Detector: } 280^{\circ} \mathrm{C}\end{array}$ & $\begin{array}{l}\text { HA: } \\
\text { Urine: } 16.5 \\
\text { ng/mL } \\
\text { Water: } \\
12.1 \\
\text { ng/mL }\end{array}$ & [68] \\
\hline
\end{tabular}

${ }^{a} \mathrm{HCl}$, Hydrochloric acid; $\mathrm{NaOH}$, Sodium hydroxide; $\mathrm{Na}_{2} \mathrm{SO}_{4}$, Sodium sulfate, CW/DVB, Carbowax-divinylbenzene; Direct immersion-solid phase microextraction, DI-SPME; MeOH, Methanol.

${ }^{\mathrm{b}}$ GC-FID, Gas chromatography-flame ionization detector; GC-MS, Gas chromatograph-mass spectrometry; MA, Mandelic acid; PHGA, Phenyglyoxylic acid; HA, Hippuric acid; o-, ortho; m-, meta; p-, para; mHA, methylhippuric acid.

${ }^{\mathrm{c}} \mathrm{HA}$, Hippuric acid; o-, ortho; m-, meta; p-, para; mHA, methylhippuric acid; MA, Mandelic acid; PHGA, Phenyglyoxylic acid; OA, Oxalic acid; SA, Stearic acid; FA, Furoic acid.

${ }^{\mathrm{d}} \mathrm{MeOH}$, Methanol; $\mathrm{HCl}$, Hydrochloric acid.

${ }^{\mathrm{e}} \mathrm{N}_{2}$, Nitrogen; He, Helium; TPGC, temperature programmed GC.

${ }^{\mathrm{f}}$ N.R, Not reported; HA, Hippuric acid; o-, ortho; m-, meta; p-, para; mHA, methylhippuric acid; MA, Mandelic acid; PHGA, Phenyglyoxylic acid; FA, Furoic acid; SA, Stearic acid; t-tMA, trans-trans muconic acid.

De Paiva et al. [26] developed a method for the determination of urinary ortho-cresol using solid-phase microextraction (SPME), followed by capillary GC-flame ionization detection (GC/FID). After optimization of the SPME variables and validation of the method, it was applied to analysis of $o$-cresol in urine collected from 27 workers exposed to solvents in automotive repair shops. The maximum extraction efficiency was obtained using a carbowax-divinylbenzene (CW/DVB) fiber $(70 \mu \mathrm{m})$, immersed $20 \mathrm{~min}$ in acid hydrolyzed urine added with $3 \mathrm{~g}$ 
$\mathrm{Na}_{2} \mathrm{SO}_{4}$ at $\mathrm{pH} 7.0$ and under magnetic stirring. The SPME-GC/FID method -proved to be fast, simple and can be applied to the occupational toluene biomonitoring.

A method for the determination of the organic acids directly in the urine employing derivatization with trimethyloxonium tetrafluoroborate as a methylating agent and sequential extraction by head space and direct immersion-solid phase microextraction is reported. Furoic acid, hippuric acid, methylhippuric acid, mandelic acid, phenylglyoxylic acid and trans-muconic acid contained in urine and determined by GC-ion trap-mass spectrometry/tandem mass spectrometry analysis within $20 \mathrm{~min}$ [24].

Meanwhile, Ahmadi et al. [68] described a rapid, simple and high sensitive method for extraction of hippuric acid from human urine samples by using an automated micro solid phase extraction system ( $\mu$-SPE). However in order to increase sensitivity of gas chromatography with flame ionization detector, a post derivatization procedure was developed. In this work, a polypyrrole was synthesized by chemical oxidation of the pyrrole monomer in nonaqueous solution and applied as an excellent and efficient sorbent for $\mu$-SPE. This method was successfully used to analyze trace amounts of HA in human urine samples without any interference from coexisting.

\section{Conclusion}

Biological monitoring of toluene exposure is a growing field of interest in toxicological and occupational laboratories. Chemical and biomedical analysts should be aware and have a broad knowledge to choose the most appropriate analytical method because it can remain a major problem. They are no ideal method per se but the best method selected should be able to deliver good results and compromise between several conflicting requirements.

Preliminary test is one of the indicators for screening purposes. It could be used on site for qualitative analysis with fast results using the mobile kit. The color test has proved a powerful method for preliminary test since early this decade. However, this method is not sensitive for low concentrations of toluene exposure and it can give a false results. Thus, quantitative instrumental analysis is still required for enforcement and research purposes such as using GC-MS and HPLC. Indeed, in these situations, cost, length, complexity and workload problems generated by the analytical method are not necessarily major concerns. In contrast, for the routine monitoring of toluene exposure and forensic cases in industrial environment and enforcement agency, the cost per determination, simplicity and automation will be important considerations.

HPLC appears to be the primary choice for the determination of toluene metabolites. The apparatus is relatively economical, automatable and sufficiently versatile to be used for other determination in related areas such as drug monitoring or clinical toxicology that are currently of interest in the same laboratory. As previously indicated, the

analyst now has a choice between several methods, well adapted to routine and simultaneous determination of urinary metabolites of some common volatile solvents that require biological monitoring. Moreover, HPLC is also becoming an attractive tool in the growing field of more elaborate approaches with new urinary markers such as specific conjugates or isomers.

\section{Acknowledgement}

The authors would like to acknowledge Universiti Teknologi Malaysia for facilitations and the Department of Chemistry Malaysia and the Public Relations Department of Malaysia for studentship and financial support to Mohamad Raizul Zinalibdin.

\section{References}

1. Basselt, R. C. (2002). Disposition of toxic drugs and chemical in man, 6th Edition, .Biomedical Publication, Foster City pp. $5-1200$.

2. Coopmana, V. A., Cordonniera, J. A. and de Meyere, C. A. (2005). Fatal workplace accident involving ethyl acetate: a distribution study. Forensic Science International, 154: 92 - 95.

3. Wille, S. M. R. and Lambert, W. E. E. (2004). Volatile substance abuse-post mortem diagnosis. Forensic Science International, 142: $135-156$.

4. Esmail, A., Pottier, L. and Wright, S. (1993). Deaths from volatile substances abuse in those under 18 years: results from a national epidemiological study. Archives Disorder Children, 69: 256 - 360. 
5. Ukai, H., Inui, S., Takada, S., Dendo, J., Ogawa, J., Isobe, K., Ashida, T., Tamura, M., Tabuki, K. and Ikeda, M. (1997). Types of organic solvents used in small to medium scale industries in Japan: A nationwide field survey. International Archives Occupational Environmental Health, 70: 385 - 592.

6. Yasugi, T., Kawai, T., Endo, G., Monna, T., Odachi, T., Yamaoka, K., Hariguchi, S. and Ikeda, M. (1998). Types of organic solvents used in workplaces and work environment conditions with special references to reproducibility of work environment classification. Industrial Health, 36: 223 - 233.

7. Moon, C-S., Lee, J-T., Chun, J-H. and Ikeda, M. (2001). Use of solvents in industries in Korea; experience in Sinpyeong-Jangrim indusrial complex. International Archives Occupational Environmental Health, 74: 148 152.

8. Watson, J. M. (1982). Solvent abuse: presentation and clinical diagnosis. Human Toxicology, 1: 249 - 256.

9. Lof, A., Hansen, S. H., Naslund P., Steiner, E., Wallen, M. and Hjelm, E.W. (1990). Relationship between uptake and elimination of toluene and debrisquine hydroxylation polymorphism. Clinical Pharmacology and Therapeutics, 47: $412-417$.

10. Ogata, M., Sugiyama, K. and Moriyasu, H. (1962). Studies on poisoning IV. Toluene concentration in air and urinary hippuric acid measured by paper chromatography and mass screening examination method. Acta Medica Okayama, 16: $283-292$.

11. Yacob, A. R. and Zinalibdin, M. R. (2013). Detection of hippuric acid: A glue solvent metabolite using a mobile test kit. Arabian Journal of Chemistry, 6: 115 - 120.

12. Yacob, A. R. and Said, N. (2014). Ortho-Cresol as Indicator for Toluene Exposure among Workers. $20144^{\text {th }}$ International Conference on Environment Science and Engineering, IACSIT Press, Singapore, 68: 14 -18.

13. Inoue, O., Seiji, K., Suzuki, T., Watanabe, T., Natkasuka, H., Satao, H. and Ikeda, M. (1991). Simultaneous determination of hippuric acid,o-, $\mathrm{m}$-, and p -methylhippuric acid, phenylglyoxylic acid, and mandelic acid by HPLC . Bulletin Environmental Contamination. Toxicology, 47: $204-210$.

14. Yang, Y. D. (1998). Simultaneous determination of creatine, uric acid, creatinine and hippuric acid in urine by high performance liquid chromatography. Biomedical Chromatography, 12 (2): 47 - 49.

15. Poggi, G., Giusiani, M., Palagi, U., Paggiaro, P. L., Loi, A. M., Dazzi, F. and Baschieri, L. (1982). Highperformance liquid chromatography for the quantitative determination of the urinary metabolites of toluene, xylene, and styrene. International Archives of Occupational and Environmental Health, 50(1): 25 - 31.

16. Ogii K. (1988). Determination of Hippuric Acid in Cadaveric Urine and Urinary Stain by High Performance Liquid Chromatography. Journal Tokyo Woman Medicine Collection, 58: 627 - 636.

17. Fujii T., Kawabe S., Horike T., Taguchi T. amd Ogata M. (1999). Simultaneous Determination of the Urinary Metabolites of Toluene, Xylene and Styrene using High Performance Capillary Electrophoresis: Comparison with High Performance Liquid Chromatography. Journal Chromatography B. 41: 730 -740.

18. Lee, C. E., Lee, J., Lee, J., Eom, H.Y., Kim, M. K., Suh, J. H., Yeom, H., Kim, U., Youm, J. R. and Han, S. B. (2009). Rapid HPLC Method for the Simultaneous Determination of Eight Urinary metabolites of toluene, xylene and styrene. Bulletin Korean Chemical Society, 30(9): 2021 - 2026.

19. Inoue, O., Kanno, E., Yusa, T., Kakizaki, M., Ukai, H., Okamoto, S., Higashikawa, K. and Ikeda, M. (2002). Urinary benzylmercapturic acid as a marker of occupational exposure to toluene. International Archives Occupational Environmental Health, 75: 341 - 347.

20. Inoue, O., Kanno, E., Kasia, K., Ukai, H., Okamoto, S. and Ikeda, M. (2004). Benzylmercapturic acid is superior to hippuric acid and o-cresol as a urinary marker of occupational exposure to toluene. Toxicology Letter, 147: $177-186$.

21. Serap, A. A., Pembe, O., Yusuf, K.., Huseyin. K. and Suheyla, E. (2001). Medicolegal Aspects of Blood-Urine Toluene and Urinary Ortho-Cresol concentration in Toluene Exposure. Turkish Journal Medical Science, 31: $415-419$.

22. Monteiro, C., Franco, J. M., Proença, P., Castañera, A., Claro, A., Vieira, D. N. and Corte-Real, F. (2014). Qualitative and quantitative analysis of a group of volatile organic compounds in biological samples by HSGC/FID: application in practical cases. Forensic Science International, 243: 137 -143.

23. De Carvalho, D., Lanchote, V. L., Bonato, P. S., Queiroz, R. H. C., Santos, A. C. and Dreossi S. A. C. (1991). A new derivatization procedure for the analysis of hippuric acid and m-methyl-hippuric acid by gas chromatography. International Archive Environmental Health, 63: 33 - 37. 
24. Pacenti, M., Dugheri, S., Villanelli, F., Bartolucci, G., Calamai, L., Boccalon, P., Arcangeli, G., Vecchione, F., Alessi, P., Kikic, I. and Cupelli, V. (2008). Determination of organic acids in urine by solid-phase microextraction and gas chromatography-ion trap tandem mass spectrometry previous 'in sample' derivatization with trimethyloxonium tetrafluoroborate. Biomedical Chromatography, 22: 1155 - 1163.

25. Kongtip, P., Vararussami, J. and Pruktharathikul, V. (2001). Modified method for determination of hippuric acid and methylhippuric acid in urine by gas chromatography. Journal of Chromatography B: Biomedical Sciences and Applications, 751(1): 199 - 203.

26. De Paiva, M. J. N., Martins, I. and de Siqueira, M. E. P. B. (2007). Analysis of o-cresol in urine by solid phase microextraction capillary gas chromatography. Journal Brazillian Chemical Society, 18 (5): 1034 -1039.

27. Truchon, G., Tardif, R. and Brodeur, J. (1996). Gas chromatographic Determination of urinary o-cresol for the monitoring of toluene exposure. Journal of Analytical Toxicology, 20: 309 - 312.

28. Ikeda, M. (1996). Selected solvents.4.6 Toluene. In: Mikheev MI (ed) Biological monitoring of chemical exposure in workplace. World Health Organization, Geneva, (1) 4: 205 - 217.

29. Ikeda, M. and Ohtsuji, M. (1969). Significance of urinary hippuric acid determination as an index of toluene exposure. British Journal Industrial Medicine, 26: 244 - 246.

30. Lauwerys, R. (1983). Toluene In: Alessio L, Berlin A, Roi R, Boni M (eds) Human biological monitoring of industrial chemicals, Joint Research Centre Ispra Establishment CEC 1: 159 - 175.

31. Siqueira, M. E. and Paiva, M. J. (2002). Hippuric acid in urine: references values. Revision Saude Publica, 36: $723-727$.

32. Sugita, M., Aikawa, H., Suzuki, K., Yamasaki, T., Minowa, H., Etoh, R. and Kasuga, H. (1988). Urinary hippuric acid excretion in everyday life. Tokai Journal Exposure Clinical Medical, 13: 185 - 190.

33. Villanueva, M. B., Jonai, H., Kanno, S. and Takeuchi, Y. (1994). Dietary sources and background levels of hippuric acid in urine; comparison of Philiphine and Japanese levels. Industrial Health, 32: 339 - 346.

34. Michitsuji, H., Ohara, A., Yamaguchi, K. and Fujiki, Y. (1987). Effect of intake of refreshments in excretion of hippuric acid in urine. Matsushita Medical Journal, 26: 105 - 116.

35. Kawai, T., Yamauchi, T., Miyama, Y., Sakurai, H., Ukai, H., Takada, S., Ohashi, F. and Ikeda, M. (2007). Benzyl alcohol as a marker of occupational exposure to toluene. Industrial Health, 95: 143 - 150.

36. Hasegawa, K., Shiojima, S., Koizumi, A. and Ikeda M. (1983). Hippuric acid and o-cresol in the urine of workers exposed to toluene. International Archive Occupational Environmental Health, 52: 197 - 208.

37. Nise, G. (1992). Urinary excretion of o-cresol and hippuric acid after toluene exposure in rotogravure printing. International Archives Occupational Environmental Health, 63: 377 - 381.

38. Maestri, L., Ghittori, S. and Imbriabu, M. (1997). Determination of specific mercapturic acids as an index of exposure to environmental benzene, toluene and styrene. Industrial Health, 35: 489 - 502.

39. Angerer, J., Schildbach, M. and Kramer, A. (1998). S-p-toluylmercapturic acid in the urine of workers exposed to toluene; a new biomarker for toluene exposure. Archives Toxicology, 72: 119-123.

40. Inoue, O., Seiji, K. and Watanabe T. (1993). Effect of smoking and drinking on excretion of hippuric acid among toluene exposed workers. International Archives Occupational Environmental Health, 64: 425 - 430.

41. Kawai, T., Mizunuma, K., Okada, Y., Horiguchi, S. and Ikeda, M. (1996). Toluene itself as the best urinary marker of toluene exposure. International Archives Occupational Environmental Health, 68: 289 - 297.

42. Lovreglio, P., Barbieri A., Carrieri, M., Sabatini, L., Fracasso, M.E., Doria, D., Drago, I., Basso, A., D’Errico, M. N., Bartolucci, G.. B., Violante, F. S. and Soleo, L. (2010). Validity of new biomarkers of internal dose for use in the biological monitoring of occupational and environmental exposure to low concentrations of benzene and toluene. International Archives Occupational Environmental Health, 83: 341 - 356.

43. Park S. W., Kim N. Y., Yang Y. G, Seo B. and Paeng K. .J. (1998). Toluene Distribution of Glue Sniffers Biological Fluid Samples in Korea. Journal of Forensic Science, 43: 888 - 890.

44. Anderson C. E. and Loomis G.. A. (2003). Recognition and Prevention of Inhalant Abuse. American Academy Family Physician, 68: 869 - 874.

45. Ameno K., Fuke C., Ameno S., Kirui T., Sogo K. and Ijiri I. (1989). A Fatal Case of Oral Ingestion of Toluene. Journal Forensic Science International, 41: 255 - 260.

46. Yamazaki K., Tanaka E. and Misawa S. (1992). Urinary ortho-cresol Concentrations as an Indicator of Toluene Inhalation in Glue Sniffer. Journal Forensic Science, 32: 215 - 223. 
47. Zuppi C., Rossetti D. V., Vitali A., Vincenzoni F., Giardina B., Castagnola M. and Messana I. (2003). Determination of Urinary Hippuric Acid by Micellar Electrokinetic Capillary Chromatography. Journal Chromatography B, 793: 223 - 228.

48. Amorim L. C. A. and Alvarez-Leite E. M. (1997). Determination of o-cresol by Gas Chromatography and Comparison with Hippuric Acid Levels in Urine Sample of Individuals Exposed to Toluene. Journal Toxicology Environmental Health, 30: 101 - 107.

49. World Health Organisation (WHO) (2000). Air quality guidelines for Europe. WHO Regional Publications, European Series, No. 91. 2nd edition. WHO Regional Office for Europe. Copenhagen.

50. Croes K., McCarthy P. T. and Flanagan R. J. (1994). Simple and Rapid HPLC of Quinine, Hydroxychloroquine, Chloroquine and Desethylchloroquine in Serum, whole Blood and Filter Paper Adsorbed Dry Blood. Journal Analaytical Toxicology, 18: 255 - 260.

51. Flanagan R. J., Braithwaite R. A., Brown S. S., Widdop B. and de Wolff F. A. (1995). Basic Analytical Toxicology. World Health Organization, Geneva.

52. Gaffney, G.. W., Schreier, K., Diferrante, N. and Altman, K. I. (1954). The quantitative determination of hippuric acid. Journal Biology Chemical, 206: 695 - 698.

53. Umberger, C. J. and Fiorese, F. F. (1963). Colorimetric method of hippuric acid. Clinical Chemistry, 9: 191 196.

54. Tomokuni, K. and Ogata, M. (1972). Direct colorometric determination of hippuric acid in urine. Clinical Chemistry, 18(4): 349 - 351.

55. Yoshida, M., Akane, A., Mitani, T. and Watabiki, T. (2005). Simple colorimetric semi quantitation method of hippuric acid in urine for demonstration of toluene abuse. Journal of Legal Medicine, 7(3): $198-200$.

56. Matsui, H., Kasao, M. and Imamura, S. (1978). High-performance liquid chromatographic determination of hippuric acid in human urine. Journal of Chromatography, 145(2): 231 - 236.

57. Bevine, H., Olsson, U., Hemgard, A., Kristensson, J., Palmborg, J. and Sollenberg J. (1990). High Performance Liquid Chromatographic Analysis of Hippuric Acid in Human Blood Plasma. Journal of Chromatography, 532: $45-53$.

58. Kubota, K., Horai, Y., Kushida, K. and Ishizaki, T. (1988). Determination of benzoic acid and hippuric acid in human plasma and urine by high-performance liquid chromatography. Journal of Chromatography, 425(1): 67 -75 .

59. Ogata, M. and Taguchi, T. (1987). Quantitation of urinary metabolites of toluene, xylene, styrene, ethylbenzene, benzene and phenol by automated high performance liquid chromatography. International Archives of Occupational and Environmental Health, 59(3): 263 - 272.

60. Daneshfar, A., Toulabi, P. and Sahrai R. (2010). Determination of hippuric acid in biological fluids using single drop liquid-liquid-liquid microextraction. The Royal Society of Chemistry, 2: $564-569$.

61. Moein, M. M., El-Beqqali, A., Javanbakht, M., Karimi, M., Akbari-adergani, B. and Abdel-Rehim, M. (2014). On-line detection of hippuric acid by microextraction with a molecularly imprinted polysulfone membrane sorbent and liquid chromatography-tandem mass spectromethy. Journal of Chromatography A, 1372: 55 - 62.

62. Buchet, J. P. and Lauwerys, R. R. (1973). Measurement of urinary hippuric and m-methylhippuric acids by gas chromatography. British Journal of Industrial Medicine, 30(2): 125 - 128.

63. Kira, S. (1977). Measurement by gas chromatography of urinary hippuric acid and methylhippuric acid as indices of toluene and xylene exposure. British Journal of Industrial Medical, 34: 305 - 309.

64. Veuleman, H., Van Vlem, E., Janssens, H. and Masschelein, R. (1979). Exposure to toluene and urinary hippuric acid excretion in a group of heliorotagravure printing workers. International Archives Occupational Environmental Health, 44: 99 - 107.

65. Van Roosmalen, P. B. and Drummond, I. (1978). Simultaneous determination by gas chromatography of the major metabolites in urine of toluene, xylenes and styrene. British Journal Industrial Medical, 35: 56 - 60.

66. Campbell, L., Wilson, H. K., Samuel, A. M. and Gompertz, D. (1988). Interactions of m-xylene and aspirin metabolism in man. British Journal Industrial Medical, 30: 125 - 128.

67. Sanagi, M. M., Salleh, S., Wan Ibrahim, W. A. and Abu Naim, A. (2011). Determination of organophosphorus pesticides using molecularly imprinted polymer solid phase extraction. Malaysian Journal of Analytical Sciences, 15(2): $175-183$. 
68. Ahmadi, F., Asgharloo, H., Sadeghi, S., Gharehbagh-Aghababa, V. and Adibi, M. (2009). Post-derivatization procedure for determination of hippuric acid after extraction by an automated micro solid phase extraction system and monitoring by gas chromatography. Journal of Chromatography B, 877: 2945 - 2951.

69. Ogata, M., and Taguchi, T. (1986). Quantitative analysis of urinary glycine conjugates by high performance liquid chromatography: excretion of hippuric acid and methylhippuric acids in the urine of subjects exposed to vapors of toluene and xylenes. International Archives of Occupational and Environmental Health, 58(2): 121129.

70. Ogata, M., and Taguchi, T. (1987). Quantitation of urinary metabolites of toluene, xylene, styrene, ethylbenzene, benzene and phenol by automated high performance liquid chromatography. International Archives of Occupational and Environmental Health, 59(3): 263 -272.

71. Yacob, A. R. and Zinalibdin M. R. (2010). High Performance Liquid Chromatography Determination of urinary hippuric acid and benzoic acid as indices for glue sniffer urine. World Academy of Science and Technology, 38: 973 - 978.

72. Ohashi, Y., Mamiya, T., Mitani, K., Wang, B., Takigawa, T., Kira, S. and Kataoka, H. (2006). Simultaneous determination of urinary hippuric acid, o-, m- and p- methylhippuric acids, mandelic acid and phenylglyoxylic acid for biomonitoring of volatile organic compounds by gas chromatography-mass spectrometry. Analytica Chimica Acta, 566: 167 - 171. 